\title{
Seasonal evolution of the effects of the EI Niño-Southern Oscillation on lower stratospheric water vapor: Delayed effects in late winter and early spring
}

\author{
YuJing Liao, QuanLiang Chen", and Xin Zhou \\ School of Atmospheric Sciences, Chengdu University of Information Technology and Plateau Atmosphere and Environment Key Laboratory of Sichuan \\ Province, Chengdu 610225, China
}

\begin{abstract}
Water vapor in the stratosphere makes a significant contribution to global climate change by altering the radiative energy budget of the Earth's climate system. Although many previous studies have shown that the El Niño-Southern Oscillation (ENSO) has significant effects on the water vapor content of the stratosphere in terms of the annual or seasonal mean, a comprehensive analysis of the seasonal evolution of these effects is still required. Using reanalysis data and satellite observations, we carried out a composite analysis of the seasonal evolution of stratospheric water vapor during El Niño/La Niña peaks in winter and decays in spring. The ENSO has a distinct hysteresis effect on water vapor in the tropical lower stratosphere. The El Niño/La Niña events moisten/dry out the tropical lower stratosphere in both winter and spring, whereas this wetting/dehydration effect is more significant in spring. This pattern is due to a warmer temperature in the upper troposphere and lower stratosphere during the El Niño spring phase, which causes more water vapor to enter the stratosphere, and vice versa for La Niña. This delayed warming/cooling in the lower stratosphere during the El Niño/La Niña decay in spring leads to the seasonal evolution of ENSO effects on water vapor in the lower stratosphere.
\end{abstract}

Keywords: El Niño-Southern Oscillation; stratospheric water vapor; seasonal evolution

Citation: Liao, Y. J., Chen, Q. L., and Zhou, X, (2019). Seasonal evolution of the effects of the El Niño-Southern Oscillation on lower stratospheric water vapor: Delayed effects in late winter and early spring. Earth Planet. Phys., 3(6), 489-500.

http://doi.org/10.26464/epp2019050

\section{Introduction}

Water vapor in the stratosphere is a powerful greenhouse gas and an important driver of climate variability (Solomon et al., 2010; Dessler et al., 2013; Hegglin et al., 2014). It affects the stratospheric radiation balance through longwave radiation, which is of great significance in the temperature structure of the stratosphere (Rosenlof, 2015). The photochemical and hydrothermal effects of water vapor in the stratosphere also affect atmospheric circulation (Forster and Shine, 2002; Stenke et al., 2006; Maycock and Shine, 2012). Research on trends in the stratospheric water vapor and on the factors affecting or controlling these trends has great reference value for further studies of the stratosphere-troposphere exchange and predictions of global climate change. Increases in the water vapor content of the stratosphere observed over the last few decades may have contributed significantly to both stratospheric cooling and tropospheric warming (Forster, 2001). As early as 1995, Oltmans and colleagues presented a set of water vapor profiles obtained in Boulder, Colorado, which showed a significant increase in the water vapor content of the lower stratosphere during the time period 1981-1994 (Oltmans and Hof-

Correspondence to: Q. L. Chen, chenql@cuit.edu.cn

Received 06 JUL 2019; Accepted 28 AUG 2019.

Accepted article online 27 SEP 2019.

C 2019 by Earth and Planetary Physics. mann, 1995; Oltmans et al., 2000; Rosenlof et al., 2001). The water vapor content of the stratosphere has increased by $1 \%-1.5 \%$ per year over the past 35 years; however, the water vapor content of the lower stratosphere has decreased by about $10 \%$ since 2000 (Randel et al., 2006; Solomon et al., 2010). The factors affecting or controlling changes in the water vapor content of the stratosphere have become a subject of much interest in recent years as researchers have attempted to understand the observed trends.

Observational analyses have shown that the tropical tropopause temperature (TTT) controls the amount of water vapor in the tropical lower stratosphere (TLS) through a process of dehydration (Brewer, 1949; Rosenlof and Reid, 2008; Grise and Thompson, 2012). On interannual and intraseasonal timescales, the $\Pi \pi$ is largely driven by the response of equatorial planetary waves (including tropical Rossby and Kelvin waves) to anomalous tropical convection. By contrast, the seasonal variability in the $\Pi \pi$ is also a result of the Brewer-Dobson circulation (BDC; Rosenlof, 1995). The BDC is a vertical-meridional circulation system in the stratosphere that is characterized by the ascent of tropospheric air into the stratosphere in the tropics, which then moves poleward before descending at mid to high latitudes (Chen QL and Chen YJ, 2007). The troposphere-stratosphere coupling processes associated with the BDC modulate the mass exchange between them, thereby changing the thermal and dynamic structures in the stratosphere and troposphere, which affects the temperature and wa- 
ter vapor in the stratosphere (Roscoe, 2006; Rao J et al., 2019c). The El Niño-Southern Oscillation (ENSO) corresponds to variations in tropical convection in the troposphere and in BDC in the stratosphere, and many studies have investigated its influence on the water vapor content of the stratosphere (Randel et al., 2009; Calvo et al., 2010; Simpson et al., 2011; Abalos et al., 2015). The latest research by Rao $J$ et al. (2019c) revealed that as the wave forcing becomes stronger in El Niño winter phases, the deep branch of the BDC is significantly enhanced, resulting in changes in the tropopause temperature. Gettelman et al. (2001) reported that the ENSO can modulate the water vapor content of the stratosphere by affecting the temperature and transport processes within the tropopause. Other studies have noted that typical El Niño events (the warm phase of the ENSO) have a moistening effect on the TLS (Geller et al., 2002; Hatsushika and Yamazaki, 2003; Scaife et al., 2003). Garfinkel et al. (2013b) used a comprehensive chemistry-climate model to demonstrate that El Niño events in which the sea surface temperature (SST) anomalies peak in the Eastern Pacific Ocean lead to warming at the tropopause above the warm pool region and subsequently to higher amounts of water vapor in the stratosphere. Xie F et al. (2011) found that El Niño events tend to moisten the lower stratosphere and dry the middle stratosphere, whereas La Niña events are likely to dry the lower stratosphere over a narrow band in the tropics but have a moistening effect on the entire stratosphere. Observational and integrated modeling studies have found that strong EI Niño events have a moistening effect on the lower stratosphere, whereas La Niña events have the opposite effect on the water vapor content of the lower stratosphere (Fueglistaler and Haynes, 2005).

The ENSO has strong seasonal variations. Most ENSO events develop from the summer months, peak in late fall or early winter, and then decay by the following spring (Rao J and Ren RC, 2017; Garfinkel et al., 2018). The stratospheric mean state reverses at the transition from winter to spring. The seasonality of the ENSO events and the stratospheric mean state may bring about dramatic seasonal changes in the effect of the ENSO on the water vapor content of the stratosphere. Previous studies have principally analyzed the seasonal or annual mean anomalies in the water vapor content of the stratosphere caused by the ENSO, but little research has been carried out on the effect of the ENSO on seasonal evolution of the water vapor content of the TLS. Garfinkel et al. (2013a) noted that the differences in the impact of El Niño on the lower stratospheric water vapor may depend on the season (winter or spring). Calvo et al. (2010) and Konopka et al. (2016) showed significant effects of the ENSO on the water vapor content of the lower stratosphere in the boreal winter. The effects of seasonal variation in the ENSO on the water vapor content of the lower stratosphere and the associated dynamic processes are still unclear. Our study therefore focuses on seasonal evolution of the response of the water vapor content of the TLS to the ENSO, to clarify the different spatiotemporal characteristics and physical mechanisms.

This article is organized as follows. Section 2 describes the data and methods used in this study; Section 3 discusses seasonal evolution of the effects of El Niño/La Niña events on the water vapor content of the lower stratosphere; and Section 4 presents an ana- lysis of the associated dynamic mechanisms. Our conclusions are discussed in Section 5.

\section{Data and Methods}

\subsection{Observational Data}

Monthly mean water vapor and temperature data were primarily obtained from the European Center for Medium-Range Weather Forecasts-Interim Reanalysis (ERA-Interim) data set from 1979 to 2017, which has a horizontal resolution of $0.5^{\circ} \times 0.5^{\circ}$. In addition, we used the Modern-Era Retrospective Analysis for Research and Applications, Version 2 (MERRA-2) reanalysis data set from 1980 to 2017, which has a horizontal resolution of $0.5^{\circ} \times 0.625^{\circ}$. The MERRA-2 is the first long-term global reanalysis to assimilate space-based observations of aerosols and represent their interactions with other physical processes in the climate system. The MERRA-2 data set, which begins in 1980, was introduced to replace the original MERRA data set as advances were made in the assimilation system that enabled the assimilation of modern hyperspectral radiance and microwave observations, along with GPS radio occultation data sets. This data set also uses National Aeronautics and Space Administration (NASA) ozone profile observations that began in late 2004. Additional advances in both the Goddard Earth Observing System (GEOS) model and the Gridpoint Statistical Interpolation (GSI) assimilation system are included in MERRA-2. The spatial resolution remains about the same as in MERRA, at $0.5^{\circ} \times 0.625^{\circ}$. Along with the enhancements of MERRA-2 in meteorological assimilation, significant steps have been taken toward the Global Modeling and Assimilation Office (GMAO) target of an Earth System Reanalysis. To verify the reanalysis results, Stratospheric Water and Ozone Satellite Homogenized (SWOOSH) satellite water vapor measurements from 1984 to 2017 were also used and compared with those of ERA-Interim. The SWOOSH data set is a merged record of stratospheric ozone and water vapor measurements recorded by a number of limb-sounding and solar occultation satellites over the past 30 years. The primary SWOOSH product consists of monthly zonal mean values on a pressure grid and data from the Stratospheric Aerosol and Gas Experiment (SAGE) II /III, Upper Atmosphere Research Satellite (UARS) Halogen Occultation Experiment (HALOE), UARS Microwave Limb Sounder (MLS), and Aura MLS instruments from 1984 to the present.

\subsection{ENSO Events}

El Niño-Southern Oscillation events are represented by the Oceanic Niño Index (ONI), which is a marine El Niño index defined by the U.S. National Oceanic and Atmospheric Administration (NOAA) based on the sliding average of SST anomalies over three consecutive months in the Niño 3.4 regions $\left(5^{\circ} \mathrm{S}-5^{\circ} \mathrm{N}, 120-170^{\circ} \mathrm{W}\right)$ from 1950 to the present. El Niño events are characterized by a positive ONI greater than or equal to $+0.5{ }^{\circ} \mathrm{C}$ for five consecutive months, and La Niña events are characterized by a negative ONI less than or equal to $-0.5^{\circ} \mathrm{C}$ for five consecutive months. According to the ONI, $10 \mathrm{El}$ Niño events and 13 La Niña events occurred in the 39 years from 1979 to 2017 . The specific years in which the ENSO events occurred are listed in Table 1 and are compared with the ENSO events selected by Garfinkel et al. (2018). The years of 
Table 1. El Niño-Southern Oscillation events during the period 1979-2017

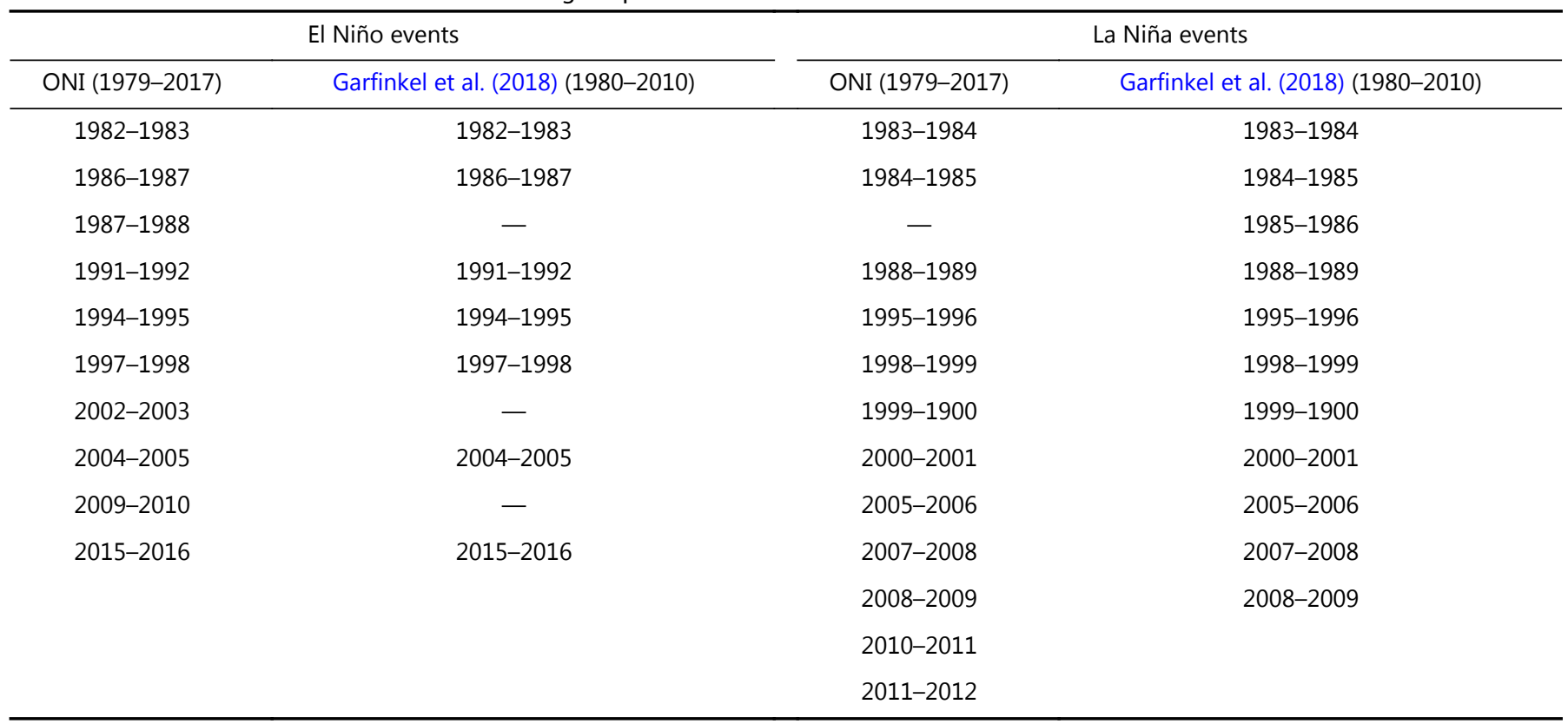

most of their El Niño and La Niña events are consistent with the results of our study, but the 1987-1988, 2002-2003, and 2009-2010 El Niño events differ, possibly because of the different areas of SST anomalies selected to define the El Niño events. Because most ENSO events peak in winter and decay the following spring, we regard December, January, and February (DJF) as winter and the following March, April, and May (MAM) as spring. In each of these periods, the stratospheric circulation has the same seasonal character.

\subsection{Analytical Methods}

Monthly anomalies were calculated by subtracting the long-term mean of each calendar month from each individual month. To avoid the possible interference of the stratospheric quasi-biennial oscillation (QBO) within the stratospheric ENSO signals, we filtered out the biennial circulation anomalies (24-32 months) from water vapor and temperature between 100 and $10 \mathrm{hPa}$, although the composite results based on the unfiltered anomalies showed little difference (Rao J and Ren RC, 2016, 2017, 2018; Ren RC et al., 2017). Wave activity analysis was used to investigate stationary Rossby wave energy propagation (Edmon et al., 1980; Randel, 1987). To demonstrate the anomalous planetary wave activity, we followed the method of Andrews et al. (1987) to calculate the twodimensional (2-D) quasi-geostrophic Eliassen-Palm (E-P) flux and its divergence in spherical coordinates. The meridional $\left(F_{y}\right)$ and vertical $\left(F_{z}\right)$ components of the E-P flux and the E-P flux divergence $\left(D_{F}\right)$ are expressed as

$$
\begin{gathered}
F_{y}=-\rho_{0} a \cos \varphi \overline{u^{\prime} v^{\prime}}, \\
F_{z}=-\rho_{0} a \cos \varphi \frac{R f}{H N^{2}} v^{\prime} T^{\prime}, \\
D_{F}=\frac{\nabla \cdot F}{\rho_{0} a \cos \varphi}=\frac{\partial\left(F_{y} \cos \varphi\right) /(a \cos \varphi) \partial \varphi+\partial F_{z} / \partial z}{\rho_{0} a \cos \varphi},
\end{gathered}
$$

where $\rho_{0}$ is the air density, $a$ is the radius of the earth, $\varphi$ is the latitude, $R$ is the gas constant, $f$ is the Coriolis parameter, $H$ is the at- mospheric scale height (7 km), $N$ is the buoyancy frequency, $T$ is the temperature, $u$ and $v$ are the zonal and meridional wind components, and $z$ is the log- $p$ height. The overbar denotes the zonal mean, and primes denote departures from the zonal mean.

\section{Results}

\subsection{Seasonal Evolution of the ENSO Effects on the Water Vapor Content of the Stratosphere}

We now consider the seasonality of the ENSO effect in the TLS by comparing the El Niño/La Niña winters and the following spring composites based on the ERA-Interim and MERRA-2 reanalysis and the SWOOSH satellite data set.

Figure 1 shows latitude-height cross sections of the zonal mean stratospheric water vapor anomalies during El Niño/La Niña winter phases and the following spring phases from the ERA-Interim, MERRA-2, and SWOOSH data. In general, the distribution of water vapor from MERRA-2 is consistent with that from ERA-Interim, and the patterns from the reanalyses are broadly in agreement with the SWOOSH satellite results, although the amount of water vapor is slightly different in the data sets. Clearly, the lower stratosphere is anomalously wetter during El Niño events and anomalously drier during La Niña events in both winter and spring in the tropics $\left(30^{\circ} \mathrm{S}-30^{\circ} \mathrm{N}\right)$. From the perspective of seasonal evolution, during El Niño winter phases, the water vapor in the lower stratosphere is anomalously moist, at $0.12 \mathrm{ppmv}$, whereas it is wetter in the following spring phases, reaching 0.15 ppmv. This is consistent with the results of Calvo et al. (2010) and Konopka et al. (2016), who showed that El Niño events lead to an enhanced water vapor content in the spring. Previous studies that considered the annual mean water vapor content have shown the moistening effect of El Niño events (Geller et al., 2002; Hatsushika and Yamazaki, 2003; Scaife et al., 2003; Garfinkel et al., 2013a), which is the mean effect of the contribution from the El Niño winter and the following spring. During La Niña events, the lower strato- 

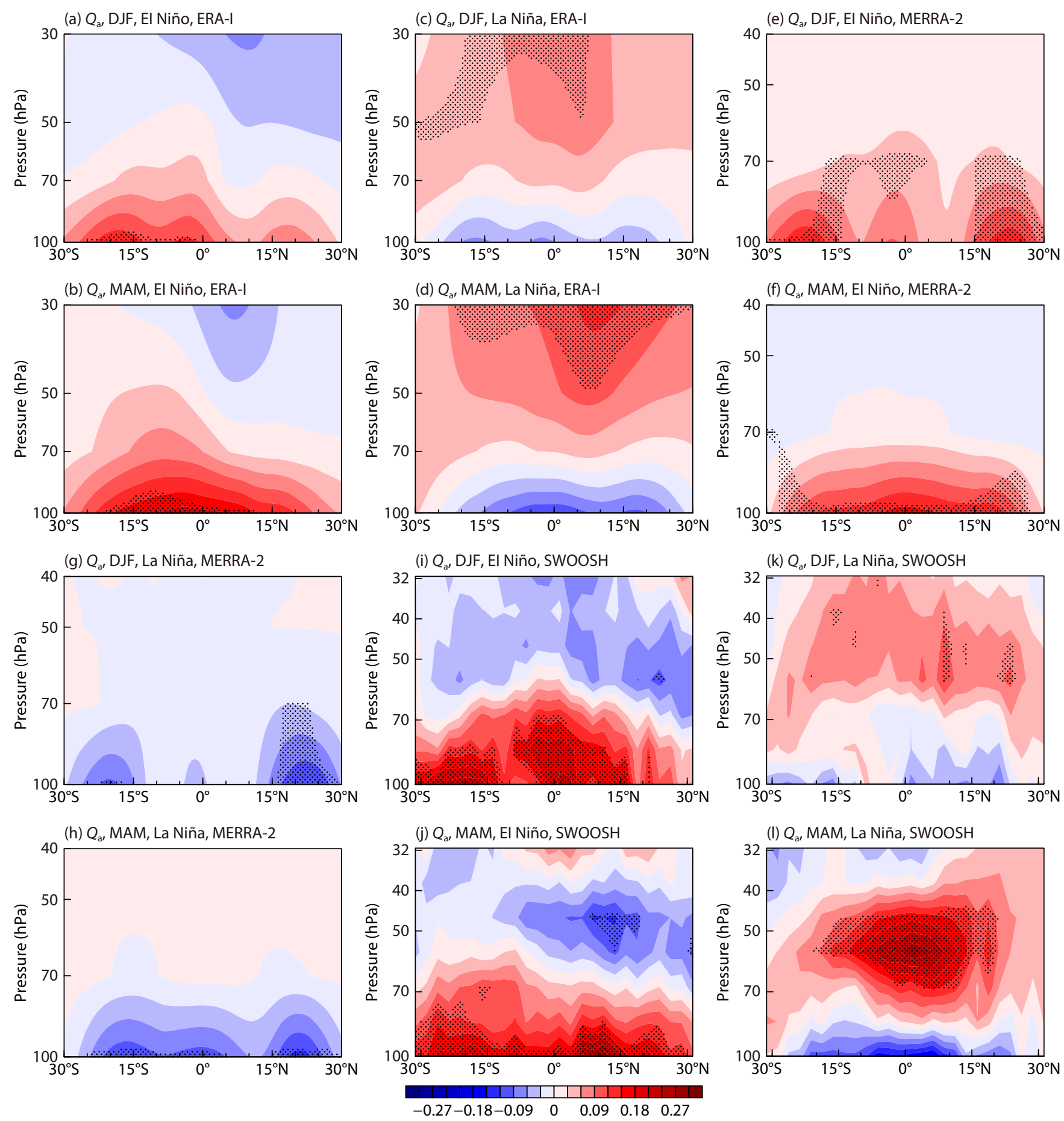

Figure 1. Latitude-height cross sections of zonal mean water vapor anomalies ( $Q_{a}$; units: ppmv) for ( $\left.a, b, e, f, i, j\right)$ El Niño and (c, d, g, h, $\left.k, l\right)$ La Niña events in the winter (DJF) and spring (MAM) based on the (a, b, c, d) ERA-Interim, (e, f, g, h) MERRA-2, and (i, j, k, l) SWOOSH data sets. Anomalies significant at the $95 \%$ confidence level according to Student's $t$-test are stippled.

spheric water vapor appears anomalously drier in winter phases, at -0.6 ppmv, but this dry condition is more significant in spring, reaching -0.12 ppmv. Overall, from winter to spring, El Niño events moisten the TLS, whereas La Niña events dry out the lower stratosphere, and both wetter and drier effects are more pronounced in the spring.

The distribution of water vapor anomalies at $100 \mathrm{hPa}$ associated with El Niño and La Niña events based on the ERA-Interim and
MERRA-2 data in the winter and spring seasons is shown in Figure 2. Similarly, the ERA-Interim results are consistent with the MERRA-2 data. The warm/cold phases of the ENSO clearly have different effects on the $100 \mathrm{hPa}$ water vapor content in different tropical regions. Furthermore, the ENSO effect on the $100 \mathrm{hPa}$ water vapor content is different in different seasons and different tropical regions. Anomalously wetter signals can be seen in the Western Pacific region and anomalously drier signals appear in the Central and Eastern Pacific regions at $100 \mathrm{hPa}$ during winter El Niño 
(a) 100-hPa $Q_{a}$, DJF, El Niño, ERA-I

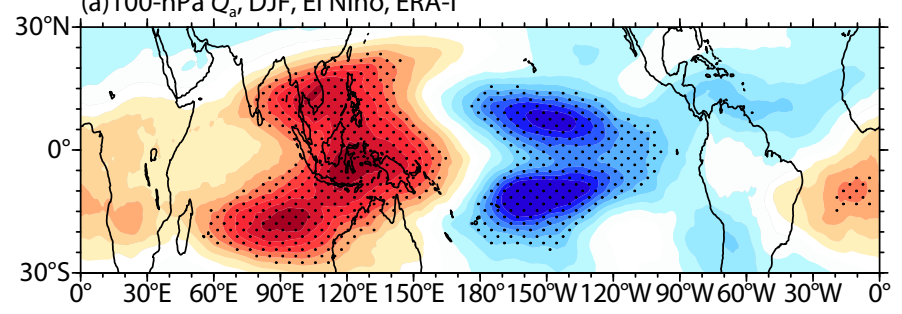

(c) 100-hPa $Q_{a}$, DJF, La Niña, ERA-I

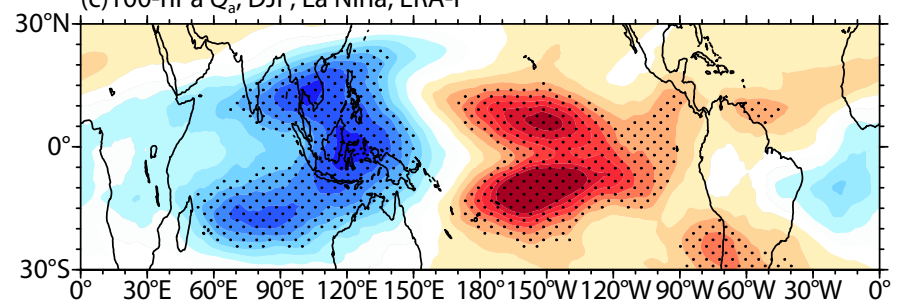

(e) 100-hPa $Q_{a}$, DJF, El Niño, MERRA-2

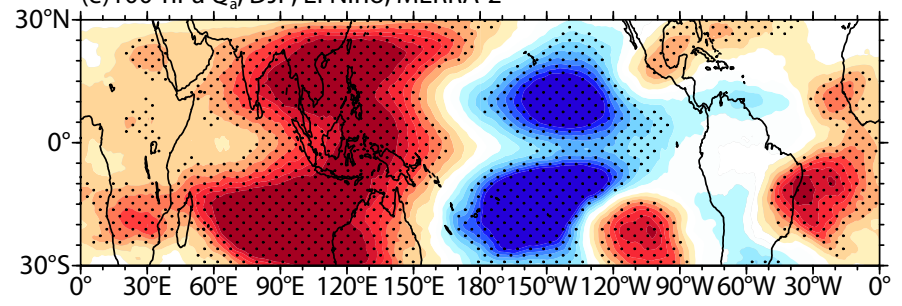

(g) 100-hPa $Q_{a}$, DJF, La Niño, MERRA-2

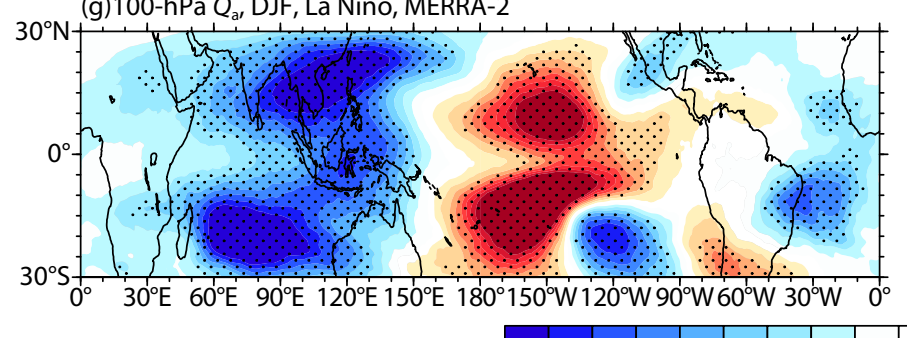

(b) 100-hPa $Q_{a}$, MAM, El Niño, ERA-I

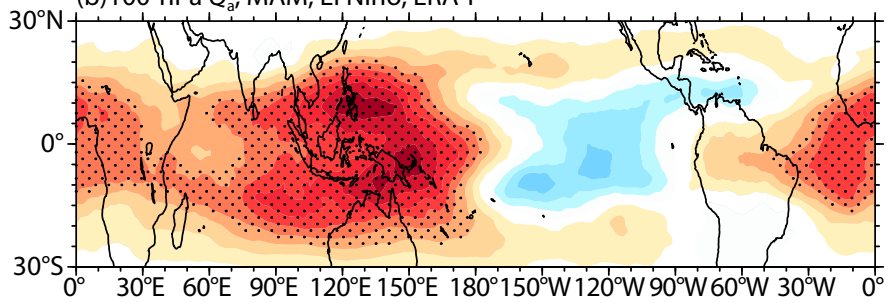

(d) 100-hPa $Q_{a}$, MAM, La Niña, ERA-I

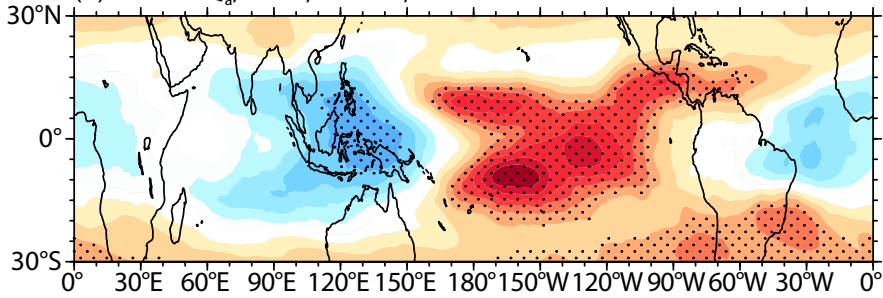

(f) $100-\mathrm{hPa} Q_{\mathrm{a}}, \mathrm{MAM}$, El Niño, MERRA-2

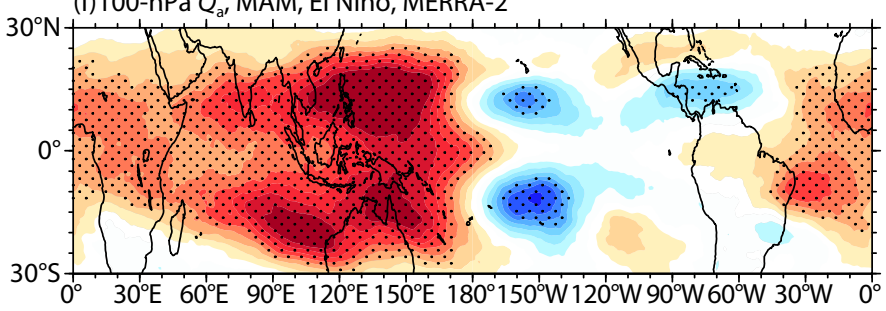

(h) 100-hPa $Q_{a}$ MAM, La Niño, MERRA-2

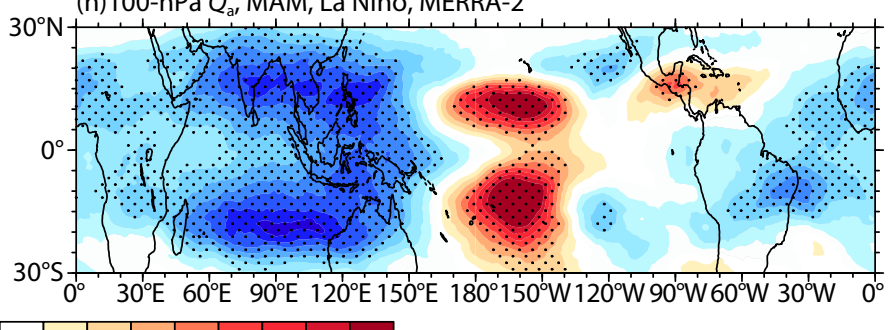

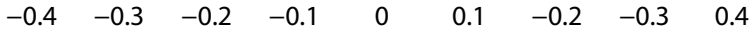

Figure 2. Water vapor anomalies ( $Q_{a}$; units: ppmv) at $100 \mathrm{hPa}$ in winter (DJF, left panels) and spring (MAM, right panels) composited for ( $\mathrm{a}$, b, e, $\mathrm{f}$ ) El Niño and (c, d, g, h) La Niña events based on the (a, b, c, d) ERA-Interim and (e, f, g, h) MERRA-2 data sets. Anomalies significant at the 95\% confidence level according to Student's $t$-test are stippled.

events. However, during the following spring, the anomalously drier signals in the Central and Eastern Pacific regions weaken and the abnormal water vapor values in this region do not pass the test of significance at a $95 \%$ confidence level. In addition, anomalously wetter signals in the Western Pacific are intensified. Note that the range of anomalously wetter signals in the Western Pacific region from MERRA-2 is wider than that from ERA-Interim. This distribution is consistent with the effect of El Niño events on the annual mean water vapor content of the stratosphere (Xie F et al., 2011). The Indo-Western Pacific region appears anomalously drier during La Niña winters, with an intensity equal to the anomalously wetter regions in the Central and Eastern Pacific. This anomalously wetter/drier region weakens in the spring. In a comparable manner, the spatial pattern of La Niña affects the water vapor in accordance with the annual mean reported in previous studies (Xie F et al., 2011).

These results show a large spatial variation in the effect of the ENSO on the water vapor content of the lower stratosphere in differ- ent seasons. Anomalously wetter/drier regions at $100 \mathrm{hPa}$ occur over the Western/Central and Eastern Pacific during El Niño/La Niña events. We therefore need to determine the net effect of El Niño/La Niña events on the water vapor content of the TLS in different seasons. Figure 3 shows the zonal mean water vapor anomalies averaged over different seasons in the tropics.

Figure $3 a-3 d$ shows the zonal mean water vapor anomalies averaged over the tropics $\left(30^{\circ} \mathrm{S}-30^{\circ} \mathrm{N}\right)$ from the ERA-Interim and MERRA-2 data sets, and Figure 3e-3f shows the anomalies from the SWOOSH satellite data set. In general, the three data sets all show seasonal variation in the lower stratospheric water vapor response to ENSO events, although the magnitudes of water vapor from the three data sets differ slightly. El Niño events show moist conditions in the winter and spring; moreover, the moisture intensifies in spring in the range of 0.09-0.15 ppmv in the ERA-Interim data. By contrast, La Niña events show anomalously dry conditions in the lower stratosphere in both seasons, and the abnormal water vapor values decrease from -0.04 to $-0.07 \mathrm{ppmv}$. As expec- 

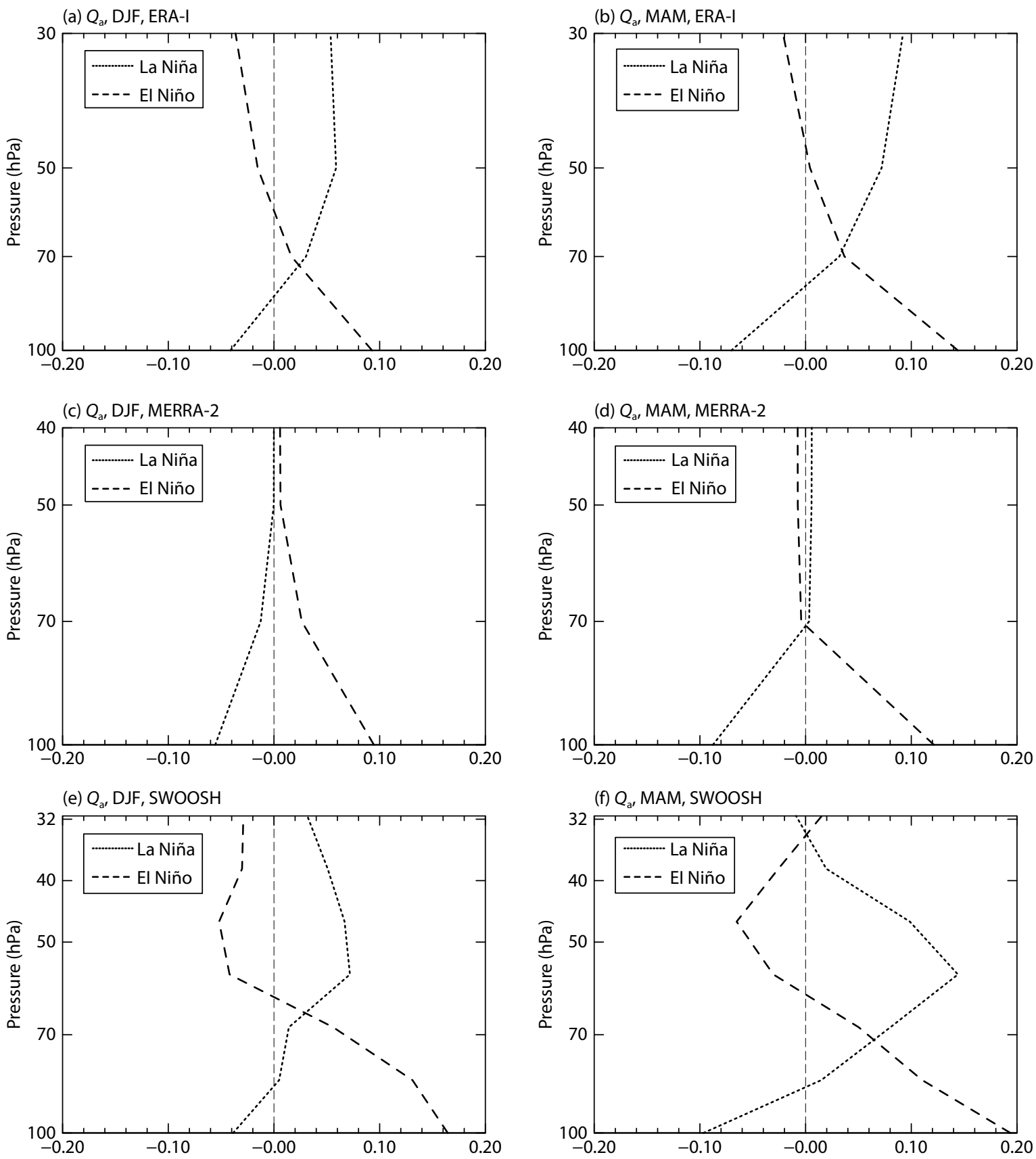

Figure 3. Vertical profiles of the zonal mean water vapor anomalies $\left(Q_{a} ;\right.$ units: ppmv) for El Niño (dashed lines) and La Niña (dotted lines) events in $(a, c, e)$ winter and $(b, d, f)$ spring based on the $(a, b)$ ERA-Interim, $(c, d)$ MERRA-2, and $(e, f)$ SWOOSH satellite data sets.

ted, the vertical distribution of MERRA-2 water vapor anomalies exhibits a pattern similar to that of ERA-Interim. Note that from winter to spring, the abnormal water vapor values of SWOOSH increase from a 0.16 to 0.20 ppmv response to El Niño but decrease from a -0.04 to -0.10 ppmv response to La Niña, distinct from the ERA-Interim anomalies. The ENSO effects on the water vapor content of the TLS in winter and spring are opposite in the cold and warm phases. El Niño events result in anomalously wet conditions, whereas La Niña events result in anomalously dry conditions. These results are consistent with previous studies; that is, El Niño events have a moistening effect on the lower stratosphere, whereas La Niña events tend to dry the TLS (Gettelman et al., 2001; Geller et al., 2002; Fueglistaler and Haynes, 2005).
To better illustrate how the seasonal evolution of ENSO affects water vapor in the lower stratosphere, the time evolution of the water vapor anomalies associated with the El Niño and La Niña events are shown in Figure 4. The results of the three data sets all suggest that the influence of ENSO events on water vapor in the lower stratosphere begins in November and lasts until the following June. El Niño events tend to moisten the lower stratosphere, whereas La Niña events are likely to dry the lower stratosphere. From winter to spring, this moistening/drying effect is more robust. During an El Niño winter, abnormal water vapor values reached $0.12 \mathrm{ppmv}$, but the moisture values peaked at $0.18 \mathrm{ppmv}$ in the spring. Similarly, La Niña events dried the lower stratosphere, and the abnormal water vapor values reached -0.09 

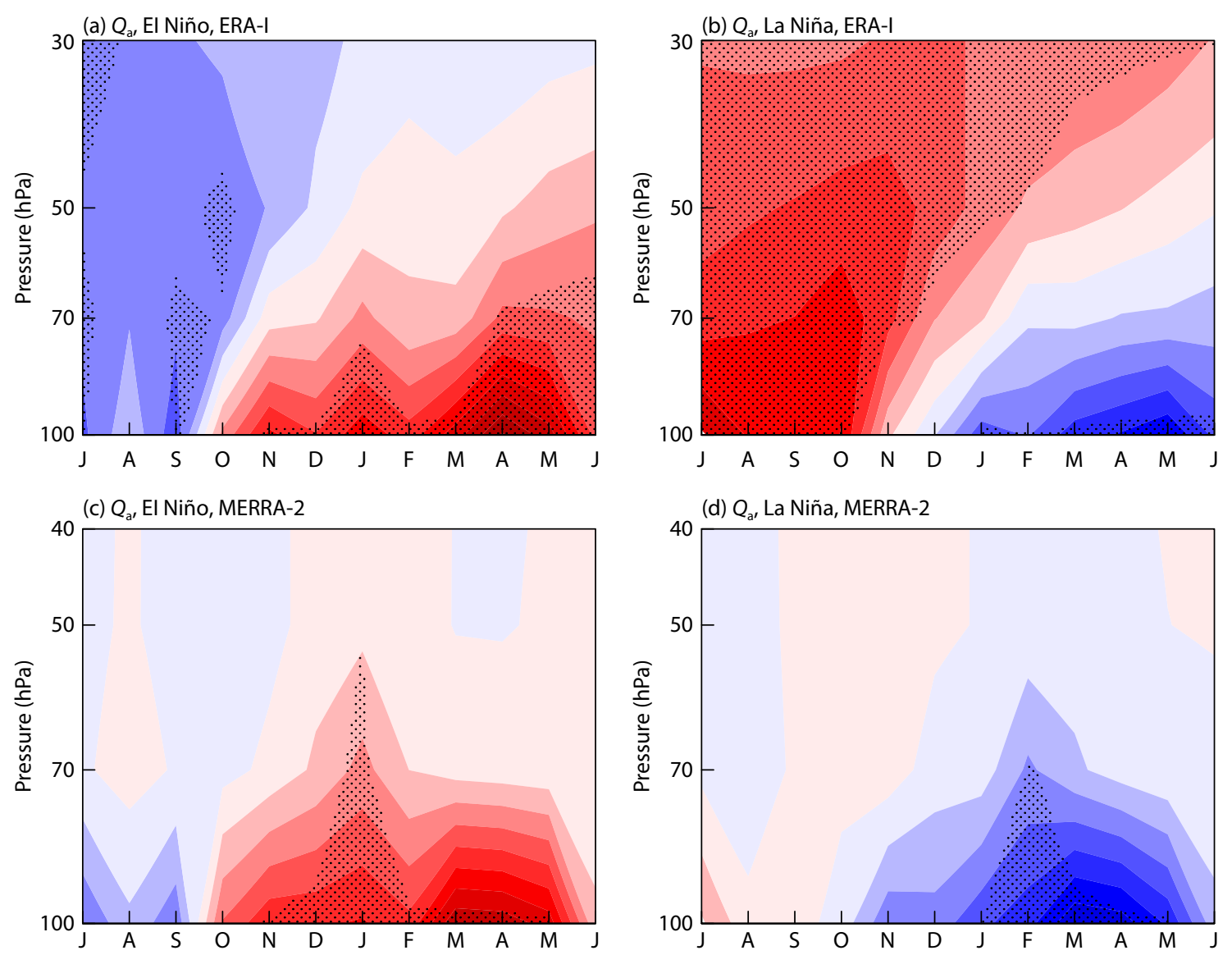

(e) $Q_{a^{\prime}}$ El Niño, SWOOSH

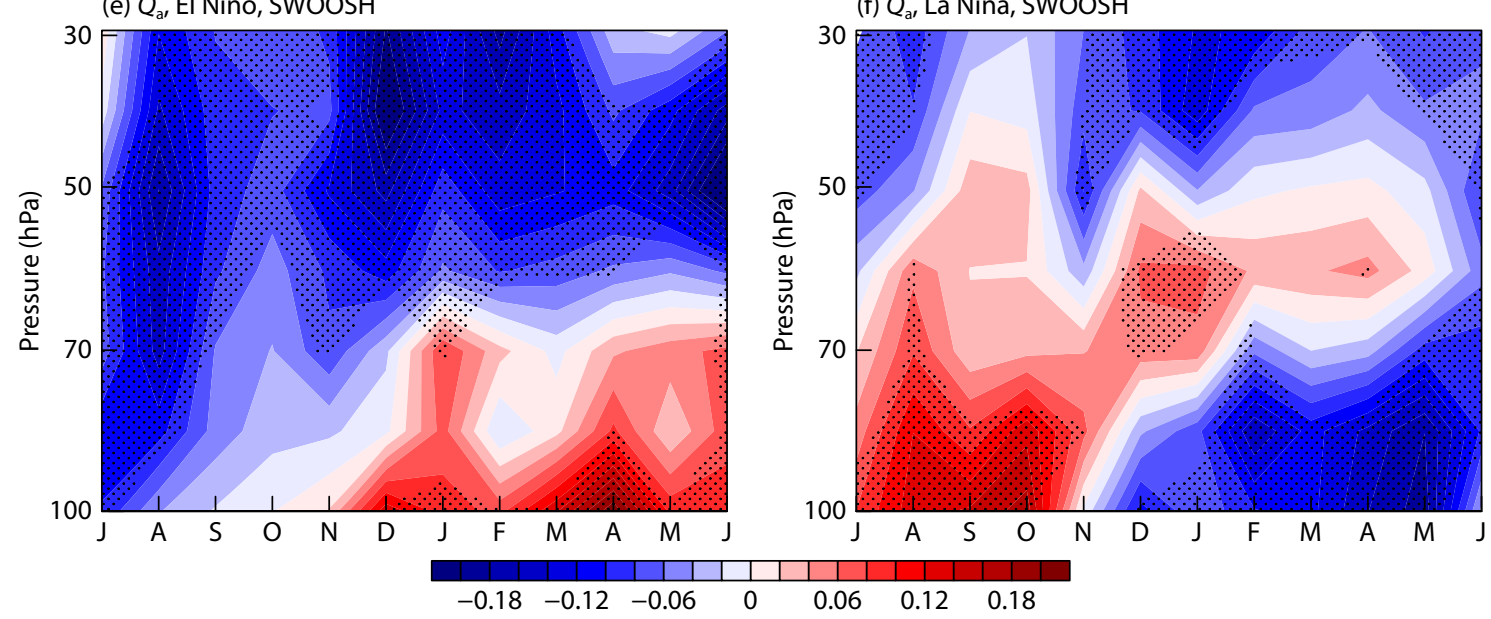

Figure 4. Time evolution of water vapor anomalies $\left(Q_{a}\right.$; units: ppmv) associated with $(a, c, e)$ El Niño and $(b$, $d$, $f$ La Niña events based on the (a, b) ERA-Interim, (c, d) MERRA-2, and (e, f) SWOOSH satellite data sets. Anomalies significant at the $95 \%$ confidence level according to Student's $t$ test are stippled.

ppmv in the winter but -0.15 ppmv in the spring. This result further confirms the conclusion illustrated in Figures 1, 2, and 3 that the influence of the ENSO on TLS water vapor intensifies in the spring.

\subsection{Mechanisms of Seasonal Variation in ENSO Effects on the Water Vapor Content of the Lower Stratosphere}

We have shown that the ENSO has distinctly different effects on the stratosphere, peaking in winter and decaying in spring. However, the mechanism that gives rise to the seasonal evolution of the ENSO effect on TLS water vapor is not well understood. In particular, the robust moistening effects of El Niño events are seen as decaying in spring rather than peaking in winter. Previous studies have emphasized the importance of studying the time evolution of the El Niño response from late winter to spring. Various authors (García-Herrera et al., 2006; Calvo et al., 2010; Ren RC et al., 2017) have found that it takes several months for the stratosphere to establish a stable pattern of response to tropical SST anomalies. We investigated the lead-lag correlation between the monthly averaged TIT and the ONI (Figure 5). The maximum cor- 


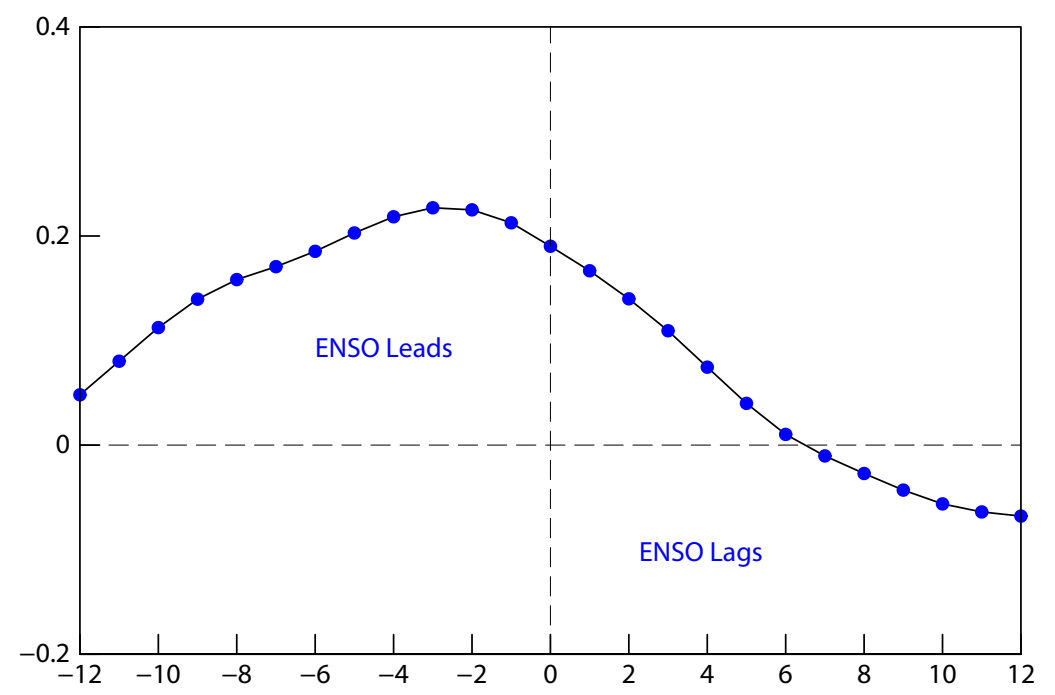

Figure 5. Lead-lag correlation between the tropical $\left(30^{\circ} \mathrm{S}-30^{\circ} \mathrm{N}\right)$ averaged tropopause temperature anomalies and the averaged Oceanic Niño Index for the period 1979-2017, from the ERA-Interim reanalysis data set. Negative lags indicate that the El Niño-Southern Oscillation (ENSO) was leading, and positive lags indicate that the ENSO was lagging.

relation coefficients occurred at a lag of 2-3 months (ENSO leading the $\Pi T$ ). This result suggests that the response of the $\Pi \Pi$ to the ENSO lagged behind the ENSO events. Therefore, we sought to explain the characteristic effects of the ENSO in different seasons by tracing back to the upper troposphere-lower stratosphere (UTLS) temperature and then investigating the processes controlling the UTLS temperature.

As mentioned previously, the water vapor entering the lower stratosphere is largely controlled by the tropopause temperature; thus, we further confirmed the seasonal evolution of the water vapor response to the ENSO by studying the temperature distribution in the winter and spring. Figure 6 shows the seasonal evolution of the zonal mean stratospheric temperature anomalies during El Niño/La Niña events. The upper troposphere was significantly warmer and the lower stratosphere was cooler during the El Niño winter phases. In the following spring, however, the upper troposphere was warmer than that in the El Niño winter and the region of warmer air extended up into the lower stratosphere. Additionally, anomalous warming in the lower stratosphere was stronger in the following spring than in the El Niño winter, leading to an increase in water vapor entering the lower stratosphere. In contrast, during La Niña events, the upper troposphere was colder and the lower stratosphere was warmer in winter, but in spring the entire lower stratosphere reversed to a cooling temperature, which was more intense than in winter. The anomalously cooler UTLS in both the La Niña winter and spring led to a drier stratosphere throughout the season (Figure 1c-1d).

The key to understanding the seasonal changes in the effects of ENSO events on the stratospheric water vapor is the delayed warming/cooling in the lower stratosphere during an El Niño/La Niña spring. Previous studies have demonstrated that EI Niño events intensify the vertical propagation of ultra-long Rossby waves in the Northern Hemisphere during winter and thereby strengthen the BDC (Rao J et al., 2019a). This effect has been seen in observational records (Van Loon and Labitzke, 1987; Labitzke and Van Loon, 1989; Camp and Tung, 2007; Garfinkel and Hartmann, 2007; Free and Seidel, 2009) and has been reproduced in modeling studies (Hamilton, 1993; Sassi et al., 2004; García-Herrera et al., 2006; Manzini et al., 2006; Taguchi and Hartmann, 2006; Xie F et al., 2012; Garfinkel et al., 2013b; Rao J and Ren RC, 2016, 2017, 2018; Rao J et al., 2019a, b, c). Therefore, we focused on the planetary wave activity during ENSO events that peak in the winter and decay in the spring. Figure 7 shows the latitude-height structure of the E-P flux anomalies in different seasons during El Niño and La Niña events. Consistent with previous studies, during El Niño winters, the planetary wave activities were found to be enhanced in the middle latitudes and to have a stronger E-P flux divergence in the Northern Hemisphere, resulting in a stronger BDC. The stratospheric upwelling associated with this strengthened BDC cools the lower stratosphere (Holton et al., 1995; García-Herrera et al., 2006; Randel et al., 2008; Rao J and Ren RC et al., 2019a). This cooling in the lower stratosphere induced by the $\mathrm{BDC}$ is present in composite temperature anomalies during $\mathrm{El}$ Niño winter seasons (Figure 6a). However, during El Niño spring seasons, reduced upward wave activities and weakened E-P flux divergence in the Northern Hemisphere lead to a weakened BDC. Consequently, the temperatures in the lower stratosphere are warmer in the spring. Compared with El Niño events, La Niña events have an overall opposite effect on the E-P flux. Therefore, changes in the E-P flux corresponding to the BDC effect explain the seasonal variation of temperature anomalies in the lower stratosphere.

\section{Discussion and Conclusions}

On the basis of the ONI, the ERA-Interim and MERRA-2 reanalysis data sets and observational data from the SWOOSH satellite were synthesized to study the seasonal evolution of ENSO impacts on water vapor in the lower stratosphere. In agreement with previous studies, the warm/cold phases of the ENSO were found to have opposite effects on the water vapor in the TLS (Fueglistaler and Haynes, 2005; Xie F et al., 2011). El Niño events tend to 

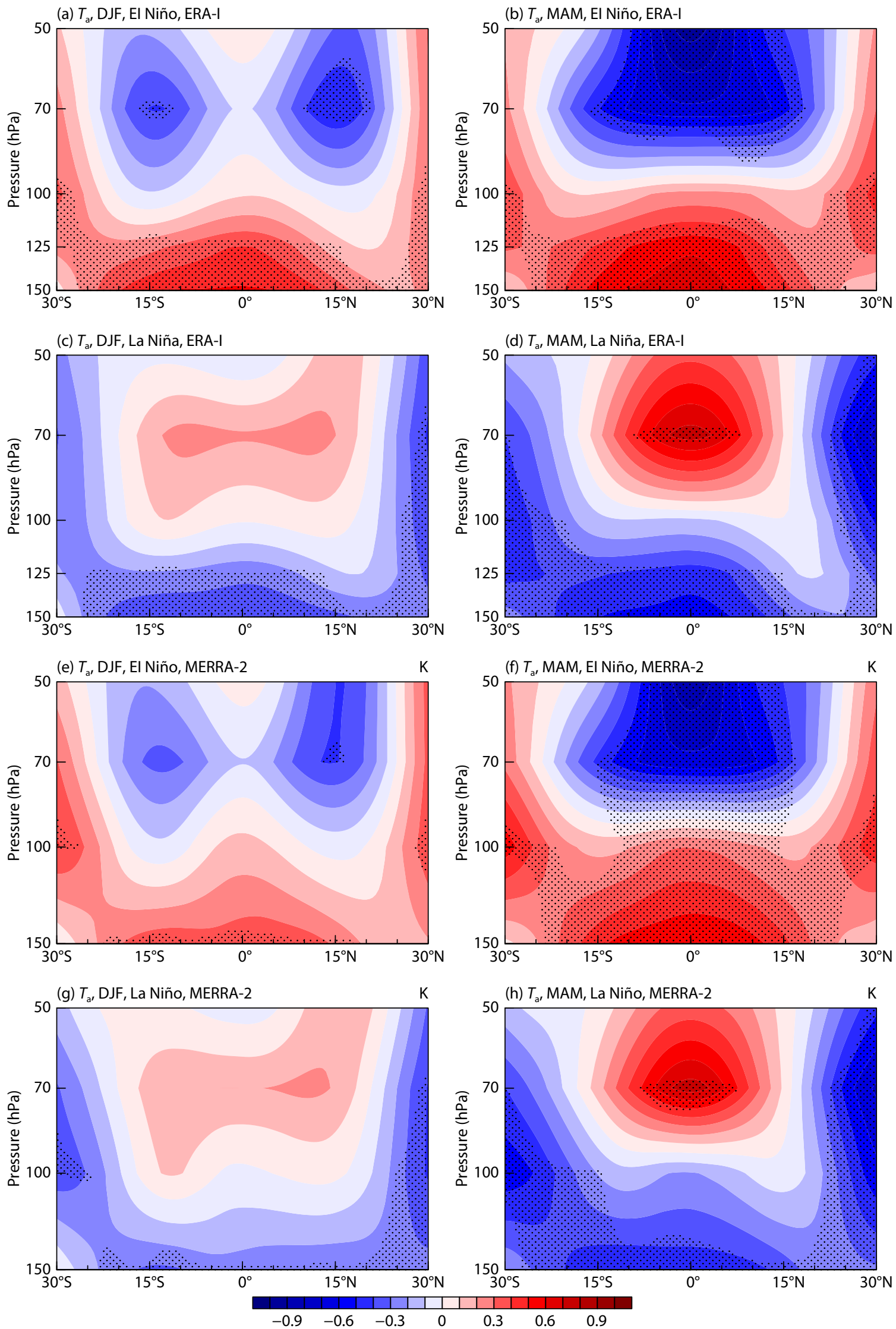

Figure 6. Latitude-height cross sections of temperature anomalies $\left(T_{a}\right.$; units: $\left.K\right)$ in $(a, c, e, g)$ winter and (b, d, f, h) spring composited for ( $a$, b, e, $f$ ) El Niño and (c, d, g, h) La Niña events based on the (a, b, c, d) ERA-Interim and (e, f, g, h) MERRA-2 data sets. Anomalies significant at the $95 \%$ confidence level according to Student's $t$-test are stippled. 
(a) EP flux, DJF, El Niño

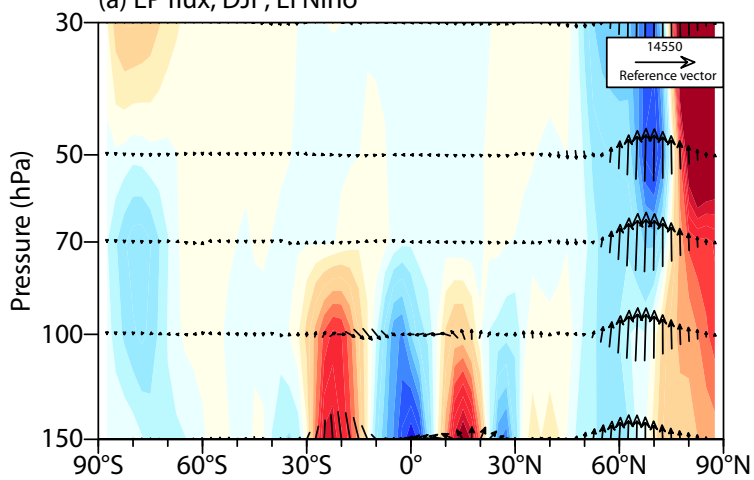

(c) EP flux, DJF, La Niño

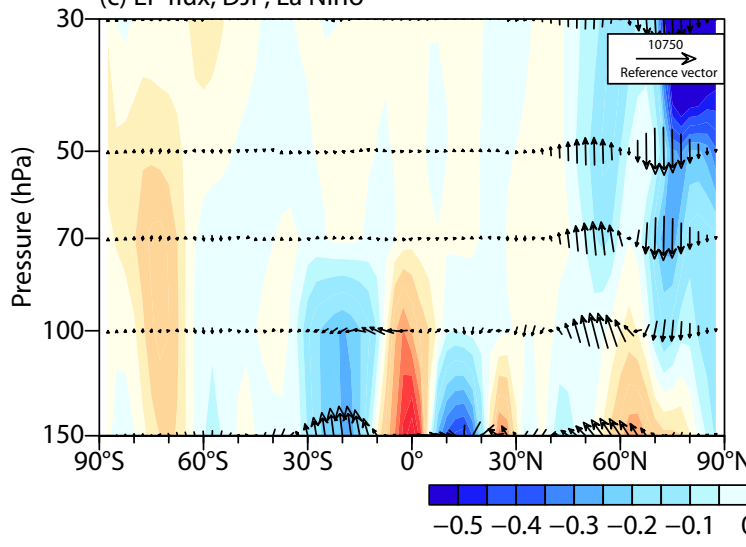

(b) EP flux, MAM, El Niño

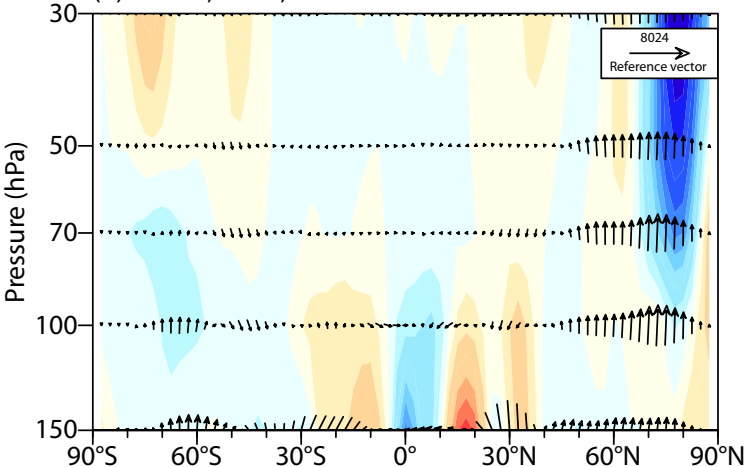

(d) EP flux, MAM, La Niña

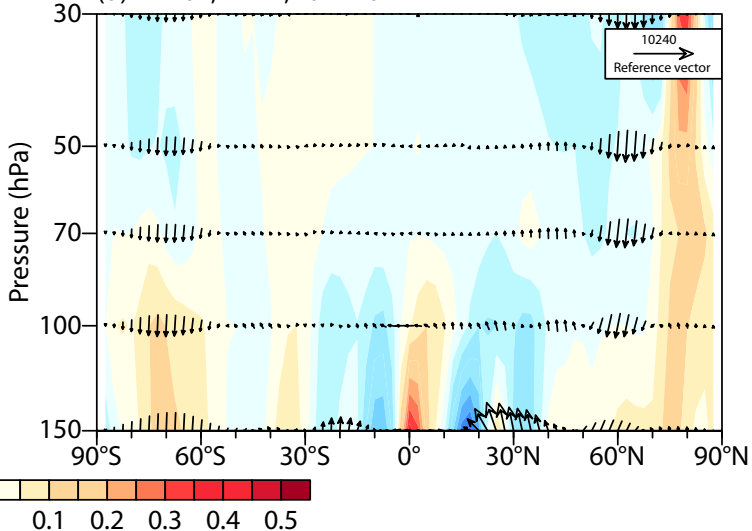

Figure 7. Distribution of Eliassen-Palm (E-P) flux (vectors, normalized by air density; units: $10^{3} \mathrm{~m}^{3} \cdot \mathrm{s}^{-2}$ ) and the E-P flux divergence (colored shading; units: $\left.\mathrm{m} \cdot \mathrm{s}^{-1} \cdot \mathrm{month}^{-1}\right)$ response to $(\mathrm{a}, \mathrm{b})$ El Niño and $(\mathrm{c}, \mathrm{d})$ La Niña events in the $(\mathrm{a}, \mathrm{c})$ winter (DJF) and (b, d) spring (MAM).

moisten the entire TLS, whereas La Niña events cause the TLS to dry out as a whole. In addition, the present results suggest that the ENSO effects on the TLS water vapor show a distinct seasonal evolution that has a hysteresis effect. From winter to spring, El Niño events moisten the lower stratosphere in winter and increase the water vapor content in spring. In contrast, La Niña events dry the TLS in both winter and spring, although this moistening/dehydration effect is more pronounced in the spring. Zhou X et al. (2018) and Ren RC et al. (2017) also noted the delayed response of the northern winter stratosphere to the ENSO. To explore the mechanisms by which the ENSO affects the lower stratospheric water vapor, we investigated the seasonal variations in UTLS temperature. The delayed warming/cooling in the lower stratosphere during El Niño/La Niña spring seasons were found to lead to a seasonal evolution of the effects of ENSO events on the lower stratospheric water vapor, which could be explained by changes in the BDC. The enhanced BDC excited by El Niño events leads to anomalous cooling in the lower stratosphere. This effect peaks in the El Niño winter but decays the following spring.

Previous studies have principally analyzed the seasonal or annual mean anomalies in the water vapor content of the stratosphere caused by the ENSO, but the present research mainly focused on the seasonal evolution of ENSO effects on water vapor in the lower stratosphere. However, several questions remain to be addressed. Recently, Garfinkel et al. (2018) used experiments based on the Goddard chemistry climate model and analyzed seasonal variation in the impacts of El Niño on the stratospheric water vapor. They suggested that El Niño dehydrates the lower stratosphere in winter but increases the water vapor content in spring, which is different from our conclusion that the El Niño moistens the lower stratosphere in both winter and spring. This discrepancy may have arisen from the use of different data sets and methodologies, as well as the small sample size of the ENSO events we used. In addition, the Eastern Pacific-type events and the Central Pacific-type events were not differentiated in this study, which may have resulted in different effects on the stratospheric water vapor. Thus, further investigation is needed in the future.

\section{Acknowledgments}

We thank the editor, T. J. Zhou, and two anonymous reviewers, whose comments improved the presentation of the paper. Funding for this study was provided by the National Key Research and Development Program on Monitoring, Early Warning, and Prevention of Major Natural Disasters (2018YFC1506006) and the National Natural Science Foundation of China (41875108).

\section{References}

Abalos, M., Legras, B., Ploeger, F., and Randel, W. J. (2015). Evaluating the advective Brewer-Dobson circulation in three reanalyses for the period 1979-2012. J. Geophys. Res. Atmos., 120(15), 7534-7554. https://doi.org/10.1002/2015JD023182

Andrews, D. G., Holton, J. R., and Leovy, C. B. (1987). Middle Atmosphere Dynamics (pp. 489). San Diego: Academic Press. 
Brewer, A. W. (1949). Evidence for a world circulation provided by the measurements of helium and water vapour distribution in the stratosphere. Quart. J. Roy. Meteor. Soc., 75(326), 351-363. https://doi.org/10.1002/qj.49707532603

Calvo, N., Garcia, R. R., Randel, W. J., and Marsh, D. R. (2010). Dynamical mechanism for the increase in tropical upwelling in the lowermost tropical stratosphere during warm ENSO events. J. Atmos. Sci., 67(7), 2331-2340. https://doi.org/10.1175/2010JAS3433.1

Camp, C. D., and Tung, K. K. (2007). Stratospheric polar warming by ENSO in winter: A statistical study. Geophys. Res. Lett., 34(4), L04809. https://doi.org/10.1029/2006GL028521

Chen, Q. L., and Chen, Y. J. (2007). Stratospheric residual circulation and its temporal and spatial evolution. Chin. J. Atmos. Sci. (in Chinese), 31(1), 137-144. https://doi.org/10.3878/j.issn.1006-9895.2007.01.14

Dessler, A. E., Schoeberl, M. R., Wang, T., Davis, S. M., and Rosenlof, K. H. (2013). Stratospheric water vapor feedback. Proc. Natl. Acad. Sci. USA, 110(45), 18087-18091. https://doi.org/10.1073/pnas.1310344110

Edmon, H. J. Jr., Hoskins, B. J., and McIntyre, M. E. (1980). Eliassen-Palm cross sections for the troposphere. J. Atmos. Sci., 37(12), 2600-2616. https://doi.org/10.1175/1520-0469(1980)037<2600:EPCSFT>2.0.CO;2

Forster, P. M. D. F. (2001). Assessing impact of stratospheric water vapor on climate. In AGU Fall Meeting. AGU Fall Meeting Abstracts. Washington: AGU.

Forster, P. M. D. F., and Shine, K. P. (2002). Assessing the climate impact of trends in stratospheric water vapor. Geophys. Res. Lett., 29(6), 10-1. https://doi.org/10.1029/2001GL013909

Free, M., and Seidel, D. J. (2009). Observed El Niño-Southern Oscillation temperature signal in the stratosphere. J. Geophys. Res. Atmos., 114(D23), D23108. https://doi.org/10.1029/2009JD012420

Fueglistaler, S., and Haynes, P. H. (2005). Control of interannual and longer-term variability of stratospheric water vapor. J. Geophys. Res. Atmos., 110(D24), D24108. https://doi.org/10.1029/2005JD006019

García-Herrera, R., Calvo, N., Garcia, R. R., and Giorgetta, M. A. (2006). Propagation of ENSO temperature signals into the middle atmosphere: $\mathrm{A}$ comparison of two general circulation models and ERA-40 reanalysis data. J. Geophys. Res. Atmos., 111 (D6), D06101. https://doi.org/10.1029/2005JD006061

Garfinkel, C. I., and Hartmann, D. L. (2007). Effects of the El Niño-Southern oscillation and the quasi-biennial oscillation on polar temperatures in the stratosphere. J. Geophys. Res. Atmos., 112(D19), D19112. https://doi.org/10.1029/2007JD008481

Garfinkel, C. I., Gordon, A., Oman, L. D., Li, F., Davis, S., and Pawson, S. (2018). Nonlinear response of tropical lower-stratospheric temperature and water vapor to ENSO. Atmos. Chem. Phys., 18(7), 4597-4615. https://doi.org/10.5194/acp-18-4597-2018

Garfinkel, C. I., Hurwitz, M. M., Oman, L. D., and Waugh, D. W. (2013a). Contrasting effects of Central Pacific and Eastern Pacific El Niño on stratospheric water vapor. Geophys. Res. Lett., 40(15), 4115-4120. https://doi.org/10.1002/grl.50677

Garfinkel, C. I., Waugh, D. W., Oman, L. D., Wang, L., and Hurwitz, M. M. (2013b). Temperature trends in the tropical upper troposphere and lower stratosphere: Connections with sea surface temperatures and implications for water vapor and ozone. J. Geophys. Res. Atmos., 118(17), 9658-9672. https://doi.org/10.1002/jgrd.50772

Geller, M. A., Zhou, X. L., and Zhang, M. H. (2002). Simulations of the interannual variability of stratospheric water vapor. J. Atmos. Sci., 59(6), 1076-1085. https://doi.org/10.1175/1520-0469(2002)059<1076:SOTIVO>2.0.CO;2

Gettelman, A., Randel, W. J., Massie, S., and Wu, F. (2001). El Niño as a natural experiment for studying the tropical tropopause region. J. Climate., 14(16), 3375-3392. https://doi.org/10.1175/15200442(2001)014<3375:ENOAAN>2.0.CO;2

Grise, K. M., and Thompson, D. W. J. (2012). Equatorial planetary waves and their signature in atmospheric variability. J. Atmos. Sci., 69(3), 857-874. https://doi.org/10.1175/JAS-D-11-0123.1

Hamilton, K. (1993). An examination of observed Southern Oscillation effects in the Northern Hemisphere stratosphere. J. Atmos. Sci., 50(20), 3468-3474. https://doi.org/10.1175/1520-0469(1993)050<3468:AEOOSO>2.0.CO;2
Hatsushika, H., and Yamazaki, K. (2003). Stratospheric drain over Indonesia and dehydration within the tropical tropopause layer diagnosed by air parcel trajectories. J. Geophys. Res. Atmos., 108(D19), 4610. https://doi.org/10.1029/2002JD002986

Hegglin, M. I., Plummer, D. A., Shepherd, T. G., Scinocca, J. F., Anderson, J., Froidevaux, L., Funke, B., Hurst, D., Rozanov, A., ... Weigel K. (2014). Vertical structure of stratospheric water vapour trends derived from merged satellite data. Nat. Geos., 7(10), 768-776. https://doi.org/10.1038/ngeo2236

Holton, J. R., Haynes, P. H., McIntyre, M. E., Douglass, A. R., Rood, R. B., and Pfister, L. (1995). Stratosphere-troposphere exchange. Rev. Geophys., 33(4), 403-439. https://doi.org/10.1029/95RG02097

Konopka, P., Ploeger, F., Tao, M. C., and Riese, M. (2016). Zonally resolved impact of ENSO on the stratospheric circulation and water vapor entry values. $J$. Geophys. Res. Atmos., 121(19), 11486-11501. https://doi.org/10.1002/2015JD024698

Labitzke, K., and Van Loon, H. (1989). Association between the 11-yr Solar Cycle, the QBO, and the atmosphere. Part III: Aspects of the association. J. Climate, 2(6), 554-565. https://doi.org/10.1175/15200442(1989)002<0554:ABTYSC>2.0.CO;2

Manzini, E., Giorgetta, M. A., Esch, M., Kornblueh, L., and Roeckner, E. (2006). The influence of sea surface temperatures on the northern winter stratosphere: ensemble simulations with the MAECHAM5 model. J. Climate., 19(16), 3863-3881. https://doi.org/10.1175/JCLI3826.1

Maycock, A. C., and Shine, K. P. (2012). Stratospheric water vapor and climate: Sensitivity to the representation in radiation codes. J. Geophys. Res. Atmos., 117(D13), D13102. https://doi.org/10.1029/2012JD017484

Oltmans, S. J., and Hofmann, D. J. (1995). Increase in lower-stratospheric water vapour at a mid-latitude Northern Hemisphere site from 1981 to 1994. Nature, 374(6518), 146-149. https://doi.org/10.1038/374146a0

Oltmans, S. J., Vömel, H., Hofmann, D. J., Rosenlof, K. H., and Kley, D. (2000). The increase in stratospheric water vapor from balloonborne, frostpoint hygrometer measurements at Washington, D.C., and Boulder, Colorado. Geophys. Res. Lett., 27(21), 3453-3456. https://doi.org/10.1029/2000GL012133

Randel, W. J., Garcia, R. R., Calvo, N., and Marsh, D. (2009). ENSO influence on zonal mean temperature and ozone in the tropical lower stratosphere. Geophys. Res. Lett., 36, L15822. https://doi.org/10.1029/2009GL039343

Randel, W. J. (1987). A study of planetary waves in the southern winter troposphere and stratosphere. Part I : Wave structure and vertical propagation. J. Atmos. Sci., 44(6), 917-935. https://doi.org/10.1175/15200469(1987)044<0917:ASOPWl>2.0.CO;2

Randel, W. J., Garcia, R., and Wu, F. (2008). Dynamical balances and tropical stratospheric upwelling. J. Atmos. Sci, 65(11), 3584-3595. https://doi.org/10.1175/2008JAS2756.1

Randel, W. J., Wu, F., Vömel, H., Nedoluha, G. E., and Forster, P. (2006). Decreases in stratospheric water vapor after 2001: Links to changes in the tropical tropopause and the Brewer-Dobson circulation. J. Geophys. Res. Atmos., 111(D12), D12312. https://doi.org/10.1029/2005JD006744

Rao, J., and Ren, R. C. (2016). Asymmetry and nonlinearity of the influence of ENSO on the northern winter stratosphere: 1. observations. J. Geophys. Res. Atmos., 121(15), 9000-9016. https://doi.org/10.1002/2015JD024520

Rao, J., and Ren, R. C. (2017). Parallel comparison of the 1982/83, 1997/98 and 2015/16 super El Niños and their effects on the extratropical stratosphere. Adv. Atmos. Sci., 34(9), 1121-1133. https://doi.org/10.1007/s00376-0176260-x

Rao, J., and Ren, R. C. (2018). Varying stratospheric responses to tropical Atlantic SST forcing from early to late winter. Climate Dyn., 51(5-6), 2079-2096. https://doi.org/10.1007/s00382-017-3998-x

Rao, J., Garfinkel, C. I., and Ren, R. C. (2019a). Modulation of the northern winter stratospheric El Niño-Southern oscillation teleconnection by the PDO. J. Climate, 32(18), 5761-5783. https://doi.org/10.1175/JCLI-D-19-0087.1

Rao, J., Ren, R. C., Xia, X., Shi, C. H., and Guo, D. (2019b). Combined impact of El Niño-Southern Oscillation and Pacific decadal oscillation on the northern winter stratosphere. Atmosphere, 10(4), 211. https://doi.org/10.3390/atmos10040211

Rao, J., Yu, Y. Y., Guo, D., Shi, C. H., Chen, D., and Hu, D. Z. (2019c). Evaluating the 
Brewer-Dobson circulation and its responses to ENSO, QBO, and the solar cycle in different reanalyses. Earth Planet. Phys., 3(2), 166-181. https://doi.org/10.26464/epp2019012

Ren, R. C., Rao, J., Wu, G. X., and Cai, M. (2017). Tracking the delayed response of the northern winter stratosphere to ENSO using multi reanalyses and model simulations. Climate Dyn., 48(9-10), 2859-2879. https://doi.org/10.1007/s00382-016-3238-9

Roscoe, H. K. (2006). The Brewer-Dobson circulation in the stratosphere and mesosphere-Is there a trend?. Adv. Space Res., 38(11), 2446-2451. https://doi.org/10.1016/j.asr.2006.02.078

Rosenlof, K. H. (1995). Seasonal cycle of the residual mean meridional circulation in the stratosphere. J. Geophys. Res. Atmos., 100(D3), 5173-5191. https://doi.org/10.1029/94JD03122

Rosenlof, K. H. (2015). STRATOSPHERIC CHEMISTRY TOPICS| stratospheric water vapor. In G. R. North, et al. (Eds.), Encyclopedia of Atmospheric Sciences (pp. 250-256). Amsterdam: Elsevier.

Rosenlof, K. H., and Reid, G. C. (2008). Trends in the temperature and water vapor content of the tropical lower stratosphere: Sea surface connection. J. Geophys. Res. Atmos., 113(D6), D06107. https://doi.org/10.1029/2007JD009109

Rosenlof, K. H., Oltmans, S. J., Kley, D., Russell, J. M., Chiou, E.-W., Chu, W. P., Johnson, D. G., Kelly, K. K., Michelsen, H. A., ... McCormick, M. P. (2001). Stratospheric water vapor increases over the past half-century. Geophys. Res. Lett., 28(7), 1195-1198. https://doi.org/10.1029/2000GL012502

Sassi, F., Kinnison, D., Boville, B. A., Garcia, R. R., and Roble, R. (2004). Effect of El Niño-Southern Oscillation on the dynamical, thermal, and chemical structure of the middle atmosphere. J. Geophys. Res. Atmos., 109(D17), 17108. https://doi.org/10.1029/2003JD004434

Scaife, A. A., Butchart, N., Jackson, D. R., and Swinbank, R. (2003). Can changes in ENSO activity help to explain increasing stratospheric water vapor?.
Geophys. Res. Lett., 30(17), 1880. https://doi.org/10.1029/2003GL017591

Simpson, I. R., Shepherd, T. G., and Sigmond, M. (2011). Dynamics of the lower stratospheric circulation response to ENSO. J. Atmos. Sci., 68(11), 2537-2556. https://doi.org/10.1175/JAS-D-11-05.1

Solomon, S., Rosenlof, K. H., Portmann, R. W., Daniel, J. S., Davis, S. M., Sanford, T. J., and Plattner, G. (2010). Contributions of stratospheric water vapor to decadal changes in the rate of global warming. Science, 327(5970), 1219-1223. https://doi.org/10.1126/science.1182488

Stenke, A., Dameris, M., and Grewe, V. (2006). Simulated trends of stratospheric water vapor from 1960 to 2020 and impact on ozone chemistry. Tagung. DLR.

Taguchi, M., and Hartmann, D. L. (2006). Increased occurrence of stratospheric sudden warmings during El Niño as simulated by WACCM. J. Climate, 19(3), 324-332. https://doi.org/10.1175/JCLI3655.1

Van Loon, H., and Labitzke, K. (1987). The Southern Oscillation. Part V: The anomalies in the lower stratosphere of the Northern Hemisphere in winter and a comparison with the quasi-biennial oscillation. Mon. Wea. Rev., 115(2), 357-369. https://doi.org/10.1175/15200493(1987)115<0357:TSOPVT>2.0.CO;2

Xie, F., Li, J. P., Tian, W. S., Feng, J., and Huo, Y. (2012). Signals of El Niño Modoki in the tropical tropopause layer and stratosphere. Atmos. Chem. Phys., 12(11), 5259-5273. https://doi.org/10.5194/acp-12-5259-2012

Xie, F., Tian, W. S., Li, J. P. (2011). The effect of ENSO activity on lower stratospheric water vapor. Atmos. Chem. Phys. Discuss., 11(2), 4141-4166. https://doi.org/10.5194/acpd-11-4141-2011

Zhou, X., Li, J. P., Xie, F., Chen, Q. L., Ding, R. Q., Zhang, W. X., and Li, Y. (2018), Does extreme El Niño have a different effect on the stratosphere in boreal winter than its moderate counterpart?. J. Geophys. Res. Atmos., 123(6), 3071-3086. https://doi.org/10.1002/2017JD028064 